\title{
RESPONS ANAK TERHADAP CERITA RAKYAT MALIN KUNDANG
}

\author{
(Kajian Resepsi Sastra) \\ Yulinda Indriani \\ yuli_indriani666@gmail.com \\ Universitas Kanjuruhan Malang
}

\begin{abstract}
Abstrak
Penelitian resepsi adalah telaah sastra yang berhubungan dengan keberterimaan pembaca, Di dalam penelitian resepsi dan satra anak ada beberapa telaah tentang teori-teori yakni hakikat dari resepsi sastra beserta pendekatan dan horison pembacanya, kajian psikologi sastra memiliki hubungan yang fungsional terhadap resepsi sastra, yakni psokologi pembaca dan psikologi pembaca anak. Teori tentang sastra anak diawali dengan hakikat sastra anak dengan beberapa jenis-jenis sastra anak. penelitian tentang kesastraan, yakni kajian resepsi sastra yang menganalisis respons anak terhadap cerita rakyat Malin Kundang. Alasan peneliti menggunakan cerita Malin Kundang karena cerita ini digemari oleh banyak orang mulai dari anak- anak sampai dewasa, selain itu banyak amanat yang terkandung di dalam cerita Malin Kundang.

Kata - kata kunci : Resepsi Sastra, Sastra Anak, Cerita Rakyat
\end{abstract}

\begin{abstract}
Reception study is a review of literature relating to the acceptability of the reader, reception in the research and study of children's literature there are several theories about the nature of literature and its reception horizon approach and its reader, study psychology literature has a functional relationship to the reception of literature, the reader psychology and child psychology reader. Theories abaout the nature of children's literature, children's literature begins with some types of children's literature. Research of literature, namely the study of the reception of literature that analyzes the child's response to foklore Malin Kundang. reason researchers use the story of Malin Kundang is favored by many people ranging from children to adults, other than that a lot of the mandate contained in the story of Malin Kundang.
\end{abstract}

Keywords : the reception of literature, children's literature, folklore

\section{Pendahuluan}

Membaca sastra di berbagai tingkat, ruang, umur, akan berbeda satu sama lain. Karenanya, membaca sastra di perguruan tinggi otomatis akan memiliki tekanan yang berbeda dengan membaca sastra di sekolah sebelumnya. Tingkat kecermatan membaca sastra (prosa, puisi, dan drama) di perguruan tinggi telah ke arah pemahaman sebagai studi (kritik dan penelitian) sedangkan di sekolah bawahnya lebih cenderung ke apresiasi biasa untuk kenikmatan. Seseorang akan menanggapi suatu karya Bukan hanya berdasarkan apa yang ada pada dirinya, tetapi juga mengacu pada kondisi tekstual yang akan dibaca. Berdasarkan konsep tersebut, dapat disimpulkan bahwa kajian yang difokuskan pada unsur-unsur tekstual yang dapat memberikan efek pada pembaca disebut wirkungsasthetik, sedangkan yang memfokuskan pada resepsi pembaca terhadap 
karya disebut rezeptionsasthetik. ( Munaris, 2011: 11) Resepsi sastra adalah pendekatan penelitian sastra yang tidak berpusat pada teks. Karena teks satra bukan satu-satunya obyek penelitian, pendekatan ini tidak murni meneliti sastra. Resepsi sastra justru meneliti teks sastra dalam kaitan tertentu. Teks sastra diteliti dalam kaitannya dengan pengaruh, yakni keberterimaan pembaca. Oleh karena dasar pemikirannya adalah teks sastra ditulis untuk disajikan kepada pembaca (Endraswara, 2011 : 118) Resepsi pembaca secara psikologis pasti akan terjadi, dibandingkan resepsi yang lain. Penerimaan nilai sastra biasanya justru berasal dari aspek psikologis. Dengan modal kejiwaan, karya sastra akan meresp secara halus dalam diri pembaca. Oleh sebab itu, pembaca yang bagus tentu mampumeneladani aspek-aspek penting dalam satra. Nilainilai dalam sastra yang mampu membentuk siakap dan perilaku, akan diinternalisasikan dalam diri pembaca. Sastra anak dapat didefinisikan dengan memperhatikan definisi sastra secara umum dan sastra bagaimana yang sesuai untuk anak. Mengenai hal ini ada beberapa pandangan berikut ini. Pertama, sastra anak adalah sastra yang sengaja memang ditujukan untuk anak-anak. Misal buku atau majalah anak-anak. Contohnya Bobo, Mentari dan lain-lain. Kedua, sastra anak berisi cerita anak. Isi cerita yang dimaksud adalah cerita yang menggambarkan pengalaman, pemahaman, dan perasaan anak.

\section{Metode}

Desain penelitian yang digunakan di dalam penelitian ini adalah kuantitatif, dengan jenis penelitian deskriptif menggunakan metode kuesioner atau angket. Pendekatan kuantitatif dipilih karena data yang akan diteliti di dalam penelitian ini berupa angka-angka dan prosentase yang dianalisis menggunakan statistik. Jenis penelitian deskriptif dipilih karena peneliti tidak perbandingan variabel itu pada sampel yang lain. Artinya disini peneliti hanya menggunakan satu variabel yakni cerita rakyat Malin Kundang yang akan dijadikan bahan resepsi sastra. Metode kuesioner atau angket digunakan untuk memperoleh data yang nantinya kuesioner tersebut akan dibagikan dan di jawab langsung oleh beberapa anak setelah mereka membaca cerita rakyat Malin Kundang terlebih dahulu. Metode kuesioner atau angket ini merupakan serangkaian pertanyaan tertulis yang ditujukan kepada responden mengenai masalah-masalah tertentu, yang bertujuan untuk mendapatkan tanggapan dari responden tersebut. Angket dapat bersifat terbuka, tertutup atau gabungan dari keduanya. Ia bersifat terbuka jika responden diberi kebebasan untuk menjawab sesuai dengan keyakinannya, tertutup jika jawaban yang harus dipilih sudah tersedia, dan gabungan keduanya jika disediakan pilihan jawaban tetapi sekaligus boleh mengisi jawaban sendiri (Nurgiyantoro, 2013:91) Analisa data dilakukan dalam beberapa tahap. Tahap pertama adalah analisis kuantitatif, yaitu mentabulasikan tiap-tiap data dari angket siswa. Tahap berikutnya, mendeskripsikan resepsi siswa terhadap cerita rakyat Malin Kundang. Untuk mengolah 
dan menganalisis data hasil angket yang telah diberikan kepada responden digunakan teknik prosentase. Hasil perhitungan tersebut diperoleh frekuensi untuk setiap butir pertanyaan.

\section{Pembahasan}

Pada penelitian awal peneliti mendapatkan beberapa temuan yakni pertama, 90\% responden lebih tertarik membaca komik dan novel dari pada cerita rakyat. Kedua, pada uji coba siklus pertama peneliti memberikan angket kepada 2 orang responden dan hasil yang didapat adalah soal pada angket yang dibuat oleh peneliti terlalu banyak, awalnya peneliti memberikan 35 soal yang kemudian disederhanakan menjadi 30 soal. Bahasa yang digunakan peneliti dalam memebuat angket sulit dimengerti oleh responden, jadi peneliti harus merubah beberapa pertanyaan. Setelah uji coba siklus pertama selesai barulah siklus kedua dijalankan, dan hasilnya sangat memuaskan, respon mereka terhadap cerita rakyat Malin Kundang berdasarkan angket yang mereka isi sangat baik. Penelitipun dapat dengan mudah menganalisis jawaban mereka, pembahasan pada analisis angket akan dijelaskan secara terperinci pada pembahasan berikut.

Penelitian ini berfungsi untuk mengetahui respon anak-anak terhadap cerita Malin Kundang, komponen yang diteliti antara lain resepsi isi cerita, resepsi tokoh, dan resepsi amanat. Responden yang diambil sebanyak 8 anak yang berumur rata-rata 8-12 tahun. Pertanyaan yang diajukan oleh peneliti sebanyak 30 pertanyaan, yang terdiri dari 15 pertanyaan pengetahuan dasar berbentuk mutiplechoise, yang kedua 10 pertanyaan esai tentang isi cerita Malin Kundang dan yang ketiga adalah 5 pertanyaan simpulan dari cerita Malin Kundang. Berdasarkan hasil analisis kuesioner respon anak terhadap cerita rakyat Malin Kundang, dengan 8 responden yang terdiri dari anak-anak usia 8-12 tahun dan 30 pertanyaan, dapat disimpulkan bahawa 8 anak (100\%) mengatakan bahwa mereka mengetahui tentang cerita Malin Kundang dan pernah membaca cerita Malin Kundang. Meskipun dapat diketahui $90 \%$ dari mereka lebih memilih bacaan sejenis komik dari pada cerita rakyat seperti Malin Kundang. Disini dapat diketahui minat mereka terhadap sastra anak tradisional seperti cerita rakyat cukup rendah, karena mereka lebih berminat pada bacaan komik. Tetapi respon mereka terhadap cerita Malin Kundang cukup tinggi, hal ini dapat dibuktikan bahwa 8 anak (100\%) mengetahui dan pernah membaca ceritanya.

Di dalam beberapa pertanyaan inti cerita, $85 \%$ dari mereka dapat menjawab pertanyaan dengan baik, hal ini terbukti bahwa mereka mampu memahami isi cerita Malin Kundang. Pemahaman mereka terhadap isi cerita malin kundang dapat dilihat dari beberapa pertanyaan yang mencakup tentang resepsi tokoh, resepsi isi cerita dan resepsi amanat. Untuk resepsi tokoh ada beberapa pertanyaan yang diberikan seperti "Siapakah tokoh utama dalam cerita Malin Kundang dan bagaimana wataknya ?" 6 
anak (85\%) menjawab bahwa Malin Kundang adalah tokoh utama di dalam cerita tersebut dan wataknya berkemauan keras, cerdas dan pandai bergaul. 1 anak $(7,5 \%)$ menjawab bahwa Malin Kundang adalah tokoh utama di dalam cerita tersebut dan wataknya jahat tidak pernah memberikan pesan kepada ibunya. 1 anak (7,5\%) menjawab bahwa Malin Kundang adalah tokoh utama di dalam cerita tersebut dan wataknya durhaka. "siapakah tokoh jahat dalam cerita Malin Kundang?" 3 anak (43\%) menjawab bahwa Malin Kundang dan istrinya adalah tokoh jahat di dalam cerita rakyat tersebut. Sedangkan 5 anak (57\%) menjawab hanya Malin Kundanglah satu- satunya tokoh jahat di dalam cerita rakyat tersebut. "jelaskan bagaimana sifat ibu Malin Kundang yang tergambar dalam cerita tersebut?" 4 anak (50\%) menjawab bahwa sifat ibu Malin Kundang di dalam cerita tersebut pekerja keras, sabar dan selalu sayang kepada anaknya. Sedangkan 4 anak (50\%) hanya menjawab sifat dari ibu Malin Kundang baik dan ramah. Dari ketiga pertanyaan tersebut dapat disimpulkan bahwa 80\% mereka dapat memahami tokoh di dalam cerita Malin Kundang dan 20\% jawaban mereka benar tetapi kurang sempurna penyampaiannya.

Di dalam resepsi cerita ada beberapa pertanyaan, antara lain "apakah isi cerita Malin Kundang menarik? Beri alasan!” 6 anak (85\%) mengatakan bahwa cerita Malin Kundang menarik dengan alasan cerita ini dapat memberikan pelajaran bagi pembacanya agar tidak mencontooh sifat buruk dari Malin Kundang. 1 anak (7,5\%) mengatakan cerita Malin Kundang menarik dengan alasan yang sedikit singkat, dia hanya menyebutkan cerita malin kundang bagus. Sedangkan ada 1 anak (7,5\%) yang berkata bahwa cerita Malin Kundang tidak menarik karena disaat malin kundang sudah kaya dia tidak mau mengakui ibunya lagi. "apakah isi cerita Malin Kundang mudah dipahami? Berikan komentarmu!" 8 anak (100\%) mengatakan bahwa cerita Malin Kundang mudah dipahami dengan berbagai komentar. 5 anak $(62,5 \%)$ mengatakan cerita Malin Kundang mudah dipahami karena ceritanya mudah dipelajari dan dimengerti. 2 anak (30\%) berkomentar bahwa cerita Malin Kundang mudah dipahami karena bagus dan jalan ceritanya tidak rumit. Sedangkan 1 anak $(7,5 \%)$ berkomentar bahwa cerita Malin Kundang mudah dipahami karena sudah sering membaca ceritanya. "apakah cerita Malin Kundang saat ini ada di dalam kehidupan nyata? Jika ada berikan contoh!" 6 anak (85\%) menjawab bahwa cerita malin kundang saat ini ada di dalam kehidupan nyata. 4 anak (70\%) memberikan contoh anak yang keinginannya tidak terpenuhi pasti akan marah kepada ibunya, dan ketika dia sudah kaya akan lupa kepada ibunya. 2 anak (15\%) memberikan contoh teman-temannya yang sering memarahi dan membantah perintah ibunya. Sedangkan 2 anak (15\%) mengatakan bahwa saat ini sudah tidak ada cerita seperti Malin Kundang di dalam kehidupan nyata tanpa memberikan contoh. "setelah kamu membaca cerita Malin Kundang coba ceritakan kembali secara singkat cerita tersebut dengan bahasamu sendiri!" 6 anak $(85 \%)$ dapat menceritakan kembali Malin Kundang dengan sempurna dan alur cerita 
yang berurutan, mulai dari latar belakang keluarga Malin Kundang kemudian Malin Kundang beranjak dewasa dan memilih untuk merantau meninggalkan ibunya setelah dia menjadi saudagar yang kaya raya dan kembali ke kampung halamannya dia lupa dan tidak mau mengakui ibunya. Terdapat 1 anak $(7,5 \%)$ yang kurang sempurna dalam menceritakan kembali Malin Kundang, alur ceritanya kurang berurutan ada beberapa bagian cerita yang tidak diceritakan kembali. Sedangkan 1 anak $(7,5 \%)$ tidak dapat menceritakan kembali cerita Malin Kundang. Dari keempat pertanyaan tersebut dapat disimpulkan bahwa 90\% responden mampu memahami isi cerita dari Malin Kundang. Respon mereka pada cerita Malin Kundang sangat baik. Terbukti dari salah satu pertanyaan di atas "Apakah isi cerita malin kundang menarik? beri alasan !" 95\% menganggap bahwa cerita Malin Kundang menarik alasannya cerita ini dapat memberikan pelajaran bagi pembacanya agar tidak mencontoh sifat buruk dari Malin Kundang. Bahkan ketika mereka harus menceritakan kembali cerita Malin Kundang , $85 \%$ mereka mampu menceritakan kembali dengan alur dan jalan cerita yang tepat.

Sedangkan untuk resepsi amanat, peneliti memberikan sebuah pertanyaan yaitu "Apa amanat yang terkandung dalam cerita Malin Kundang ?" 4 anak (50\%) mengatakan amanat yang terkandung di dalam cerita Malin Kundang adalah seorang ibu pasti sengsara dan menderita jika anaknya yang sudah menjadi orang kaya ternyata malu untuk mengakuinya sebagai ibu. Terdapat 2 anak (30\%) yang mengatakan bahwa amanat yang terkandung dalam cerita rakyat tersebut yakni jadilah anak yang patuh dan berbakti kepada orang tua dan jangan engkau durhaka kepada orang tuamu. 1 anak $(7,5 \%)$ menjawab amanat yang terkandung dalam cerita tersebut adalah kita tidak boleh durhaka kepada orang tua terutama ibu. Sedangkan ada 1 anak $(7,5 \%)$ yang jawabannya kurang lengkap karena dia hanya menjawab amanat yang terkandung dalam cerita tersebut adalah harus patuh pada orang tua. Disini dapat disimpulkan bahwa mereka memiliki pendapatnya masing-masing tentang amanat yang terkandung di dalam cerita Malin Kundang. 87,5\% mereka mampu memahami amanat yang terkandung di dalam cerita dengan memberikan pendapat yang sesuai isi cerita. Dalam pertanyaan simpulan peneliti memberikan beberapa pertanyaan, yang pertama "setelah membaca cerita Malin Kundang apa yang kamu rasakan ?" 5 anak (62,5\%) merasa sedih dan terharu setelah membaca cerita Malin Kundang tanpa memberikan penjelasan. Ada pula 2 anak (15\%) yang merasakan sebaliknya, mereka merasa senang setelah membaca cerita terebut. Sedangkan 1 anak $(7,5 \%)$ berkata bahwa setelah membaca cerita Malin Kundang dia menyadari ibu adalah pahlawan di dalam hidupnya yang membesarkan dan mengasuhnya sehingga kita harus menyayangi dan menghormati ibu. "sebutkan dua hal yang membuat kamu menyukai cerita Malin Kundang!" 4 anak (50\%) menyebutkan bahwa alasan mereka menyukai cerita Malin Kundang adalah ceritanya yang bagus dan mudah dipahami. Sedangkan 3 anak $(42,5 \%)$ menyukai cerita Malin Kundang karena amanatnya yang dapat kita petik sebagai pelajaran agar tidak meniru perbuatan buruk 
yang dilakukan oleh Malin Kundang. Terdapat 1 anak (7,5\%) yang memberikan 1 alasan saja yaitu ceritanya bagus. "menurutmu bagaimana isis cerita dan amanat yang terkandung dalam cerita Malin Kundang? Jelaskan pendapatmu!” 7 anak (92,5\%) berpendapat bahwa cerita Malin Kundang bagus karena amanatnya yang dapat kita petik dan kita jadikan pelajaran agar kita menjadi anak yang patuh dan sayang kepada orang tua. Sedangkan 1 anak (7,5\%) menjawab cerita Malin Kundang tidak bagus karena malin kundang telah menghianati ibunya sendiri. Dari ketiga pertanyaan tersebut dapat disimpulkan bahwa mereka mampu merasakan kesedihan dan keharuan di dalam cerita Malin Kundang, karena setelah membaca mereka merasakan keharuan. 95\% dari mereka menyukai cerita Malin Kundang dengan berbagai alasan yakni cerita Malin Kundang bagus dan mudah dipahami dan amanat yang terkandung di dalamnya dapat kita petik sebagai pelajaran agar tidak meniru perbuatan buruk yang dilakukan oleh Malin Kundang.

Dari 30 pertanyaan kuesioner yang diajukan kepada 8 responden anak-anak usia 812 tahun dapat disimpulkan bahwa minat mereka terhadap cerita rakyat rendah, karena cerita rakyat sudah tergeser oleh yang lebih modern seperti komik tetapi respon mereka terhadap cerita rakyat Malin Kundang sangat baik, terbukti dari beberapa pertanyaan yang diajukan mereka mampu menjawabnya dengan benar dan disertai pendapat mereka masing-masing. Ada beberapa dampak yang ditimbulkan oleh penelitian ini, yang pertama adalah dampak secara langsung bagi anak yang telah membaca cerita rakyat Malin Kundang yakni anak dapat lebih memahami cerita Malin Kundang dengan baik. Anak dapat mengerti bahwa cerita rakyat tidak kalah menarik dengan sastra modern seperti komik dan novel. Dampak yang kedua adalah dampak secara psikologis pada anak setelah membaca cerita rakyat Malin Kundang, secara psiokologis anak dapat mengambil hikmah yang terkandung di dalam cerita tersebut, daya imajinasi anak akan lebih berkembang sehingga mereka dapat membedakan perbuatan baik dan buruk para tokoh yang ada di dalam cerita. Setelah membaca cerita ini mereka merasa terharu, mereka merasa iba dan kasihan dengan ibu Malin Kundang yang tidak diakui dan dimaki-maki oleh anaknya sendiri, secara psikologis mereka sadar bahwa orang tua terutama ibu adalah seseorang yang harus selalu kita hormati dan kita patuhi. Rasa terharu adalah ungkapan psikologis dari anak-anak ini bahwa cerita ini telah benarbenar masuk ke dalam imajinasi mereka, sehingga mereka merasakan jika hal ini benarbenar terjadi kepada mereka sendiri. Dampak yang terakhir adalah dampak secarra langsung yang didapat oleh peneliti. Selain hasil penelitian ini dapat diselesaikan dengan baik, secara tidak langsung peneliti juga melestarikan cerita rakyat ini kepada anak-anak, karena saat ini cerita rakyat sudah mulai tergeser oleh sastra modern seperti komik dan novel. Peneliti juga mampu memahami karakter masing-masing anak yang diteliti, karena karakter setiap anak pada saat mengerjakan angket tersebut berbedabeda. 


\section{Penutup}

Membaca sastra di berbagai tingkat, ruang, umur, akan berbeda satu sama lain. Karenanya, membaca sastra di perguruan tinggi otomatis akan memiliki tekanan yang berbeda dengan membaca sastra di sekolah sebelumnya. Tingkat kecermatan membaca sastra (prosa, puisi, dan drama) di perguruan tinggi telah ke arah pemahaman sebagai studi (kritik dan penelitian) sedangkan di sekolah bawahnya lebih cenderung ke apresiasi biasa untuk kenikmatan. Dari 30 pertanyaan kuesioner yang diajukan kepada 8 responden anak-anak usia 8-12 tahun dapat disimpulkan bahwa minat mereka terhadap cerita rakyat rendah, karena cerita rakyat sudah tergeser oleh yang lebih modern seperti komik tetapi respon mereka terhadap cerita rakyat Malin Kundang sangat tinggi, terbukti dari beberapa pertanyaan yang diajukan mereka mampu menjawabnya dengan benar dan disertai pendapat mereka masing-masing. Karya sastra hanya artefak yang harus dihidupkan kembali dan diberi makna oleh pembaca sehingga menjdi objek estetik. Reaksi terhadap teks sastra tersebut dapat berupa sikap dan tindakan untuk memproduksi kembali, menciptakan hal yang baru, menyalin, meringkas, dan sebagainya. Sebaliknya, reaksi yang bersifat negatif mungkin pembaca akan sedih akan jengkel, bahkan antipati terhadap teks sastra.

\section{Daftar Pustaka}

Endraswara, Suwardi. 2008. Metode Penelitian Psikologi Sastra: Teori, Langkah dan Penerapannya. Yogyakarta: Media Pressindo.

Endraswara, Suwardi. 2011 (cetakan pertama). Metodologi Penelitian Sastra: Epistemologi, Model, Teori, dan Aplikasi. Yogyakarta: Caps

Hantisa, Oksinata. 2010. Kritik sosial dalam kumpulan Puisi aku ingin jadi peluru karya wiji thukul (kajian Resepsi sastra). Skripsi. Surakarta: Fakultas Keguruan dan Ilmu Pendidikan Universitas Sebelas Maret Surakarta.

Ikranegara, Tira. 2008. Cerita Rakyat: Malin Kundang. Surabaya: Serba Jaya

Indah, Tri Wulan. 2009. Persepsi siswa terhadap kenakalan remaja siswa kelas X SMA Negeri 1 Bululawang. Skripsi. Malang: Fakultas Keguruan dan Ilmu Pendidikan Universitas Kanjuruhan Malang.

Munaris. 2010. Karya Sastra Dan Pembaca: Kajian Resepsi Sastra. Tulungagung: Cahaya Abadi.

Nurgiyantoro, Burhan. 2010. Penilaian Pembelajaran Bahasa: Berbasis Kompetensi. Yogyakarta: BPFE

Pusposari, Dewi. 2012. Memahami Sastra Anak. Malang: Bayumedia Publishing Anggota IKAPI 


\section{JURNAL ILMIAH BAHASA DAN SASTRA}

Volume 5 Nomor 2 Tahun 2018

eISSN : 25494155 - pISSN : 23557083

Pradopo, Rachmat Djoko. 2013 (cetakan kelima). Beberapa Teori Sastra, Metode Kritik, Dan Penerapannya. Yogyakarta: Pustaka Pelajar

Ratna, Nyoman Kutha. 2013 (cetakan ke IV). Paradigma Sosiologi Sastra. Yogyakarta: Pustaka Pelajar

Rumidjan. 2013 (cetakan pertama). Dasar Keilmuan dan Pembelajaran Sastra Anak SD. Malang: Fakultas Ilmu Pendidikan Universitas Negeri Malang

Sugiyono. 2010 (cetakan kedua). Metode Penelitian Pendidikan: Pendekatan Kunantitatif, Kualitatif, dan R\&D. Bandung: Alfabeta

Tarigan, Henry Guntur. 2011. Dasar- dasar Psikosastra. Bandung: Angkasa

Wati, Noor Rahmi. 2002. "Analisis Resepsi Pembaca Cerpen "Koroshiya Desunoyo" Karya Hoshi Shin'Ichi (Studi Kasus terhadap 15 Orang Jepang)”. Tesis. Semarang: Jurusan Sastra Jepang, Fakultas Ilmu Budaya, Universitas Diponegoro. 